\title{
Financing of Multinational Subsidiaries: Parent Debt vs. External Debt
}

\author{
Bhagwan Chowdhry \\ and \\ Vikram Nanda \\ Revised: January 1994 \\ Forthcoming, Journal of Corporate Finance 1(2)
}

\footnotetext{
${ }^{1}$ Bhagwan Chowdhry is at the Anderson Graduate School of Management at UCLA. Vikram Nanda is at the School of Business Administration at USC. This paper was written while the first author was visiting the Hong Kong University of Science and Technology. Address all correspondence either to Bhagwan Chowdhry, Anderson Graduate School of Management at UCLA, 405 Hilgard Ave, Los Angeles, CA 90024, Phone: (310)-825-5883, Fax: (310)-206-5455, Email: bchowdhr@agsm.ucla.edu or to Vikram Nanda, School of Business Administration, University of Southern California, Los Angeles, CA 90089, Phone: (213)-740-6533, Fax: (213)-740-6650 Email: vnanda@vm.usc.edu. The authors thank Ken Lehn (the editor), an anonymous referee, David Eiteman, David Hirshleifer, Alan Shapiro, Sheridan Titman, seminar participants at the Hong Kong University of Science and Technology and the Australian Graduate School of Management and the participants at the 1993 PACAP conference and at the 1993 Academy of International Business annual meeting.
} 


\title{
Financing of Multinational Subsidiaries: Parent Debt vs. External Debt
}

\begin{abstract}
Financing a multinational subsidiary by intra-firm parent debt has the advantage that while interest payments on the debt are tax deductible, there are no offsetting bankruptcy costs. When the foreign corporate tax rate is higher than the domestic rate, since the multinational firm has incentives to exaggerate the interest rate on the intra-firm debt, the tax authorities put limits on the rate the parent is allowed to charge. Since the interest rate on external debt - which entails potential bankruptcy costs - is determined competitively in the market, this can be used as a benchmark to justify the rate charged on intra-firm debt. We show that the firm would finance the subsidiary partly by intra-firm parent debt and partly by external debt, both of equal seniority, but the firm would, sometimes, choose to pay its external debtors in full even when it is not contractually obligated to do so. For any given level of total debt financing, higher corporate tax rates in the foreign country are associated with a larger proportion of debt financing by external debt, larger interest rates and a larger probability of bankruptcy; higher corporate tax rates in the home country are associated with a smaller proportion of debt financing by external debt, smaller interest rates and a smaller probability of bankruptcy.
\end{abstract}




\section{Introduction}

Subsidiaries of multinational corporations rely heavily on intra-firm loans from parent corporations for their financing needs [See Eiteman, Stonehill and Moffett (1991), pp. 416-417 and Shapiro (1989), pp 411, 475]. The advantage of an intra-firm parent loan over external subsidiary debt is that there are no bankruptcy costs associated with internal loans. Stonehill and Stitzel (1969) argues [pp. 93]

...parent loans to foreign affiliates are often regarded as equivalent to equity investment both by host countries and the investing corporations. A parent company loan is generally subordinated to all other kinds of debt and does not represent the same threat of insolvency as an external loan. ${ }^{1}$

So why do subsidiaries use external debt financing at all ${ }^{2}$ We argue in this paper that the interest rate on external debt, since it is determined competitively in the market, can be used by the parent to justify to tax authorities the interest rate it charges on loans to the subsidiary. A strategy that uses both external as well as intra-firm parent debt may allow the multinational to minimize its overall tax burden. ${ }^{3}$

Consider a situation in which the corporate tax rate in the parent's home country is lower than the tax rate faced by its foreign subsidiary. Since interest expenses are tax deductible, this tax differential gives the parent firm an incentive to charge its subsidiary as high an interest as possible on its intra-firm loan. This argument is also discussed in Chown (1990) [pp. 49]:

\footnotetext{
${ }^{1}$ See also Shapiro (1978), Shapiro (1989), Eiteman, Stonehill and Moffett (1992).

${ }^{2}$ By external debt here, we mean external debt of the subsidiary that is not guaranteed by the parent. External debt that is guaranteed by the parent would be tantamount to intra-firm debt by the parent. Multinationals often do not guarantee the debt of their subsidiaries and sometimes do allow their foreign affiliates to go bankrupt: Shapiro (1989) cites Raytheon in Sicily and Freeport Sulphur in Cuba as examples.

The fact that multinational subsidiaries tend to use both external debt as well as intra-firm parent debt for their long-term and short-term financing needs is documented in Stobaugh (1970), Robbins and Stobaugh (1972) and Errunza (1979) among others.

${ }^{3}$ Local financing by a subsidiary may provide some protection against expropriation when the subsidiary is located in a country in which this threat is significant [Stonehill and Stitzel (1969), Shapiro (1989) and Eiteman, Stonehill and Moffett (1992)]. Also, interest rate subsidies by local governments may lead subsidiaries to use local financing [Shapiro (1989)]. The argument we make in the paper, however, applies to all external debt, whether or not it is local.

The optimal subsidiary financing may involve debt denominated in local currency. However, that does not mean that the local currency debt must be external. The parent could as well provide debt to the subsidiary that is denominated in local currency.
} 
If the parent company, Company A, pays a low rate of tax (or, which can amount to the same thing, has a tax loss carry-forward) while the subsidiary, Company $B$, has a high rate of tax, it obviously makes sense to charge the highest possible rate of interest on any loan from Company $A$ to Company B.

The tax authorities, aware of the possibility of such tax avoidance strategies, put limits on the interest rate a parent is allowed to charge its subsidiary on an intra-firm loan. Chown (1990) cites [pp. 51] the OECD Report, Transfer Pricing and Multinational Enterprise, published in 1979, which states:

Once it is established that an intra-group loan exists, the general principle is that the loan should bear interest if interest would have been charged in similar circumstances in a transaction between unrelated parties. ${ }^{4}$

Chown (1990) goes on to argue [pp. 51]:

The rate of interest should be determined by reference to the conditions in financial markets for similar loans, ${ }^{5}$...

This provides a rationale for external debt financing by subsidiaries since the higher the interest rate on external debt, the higher the rate a parent is allowed to charge on its intra-firm loan (of equal or junior priority), resulting in higher tax savings. However, there are bankruptcy costs associated with external debt financing. The optimal level and the seniority structure of the external and the intra-firm parent debt then is determined by the tradeoff between tax savings and bankruptcy costs. ${ }^{6}$ We develop a model that formalizes this tradeoff.

\footnotetext{
${ }^{4}$ Scholes and Wolfson (1992) [pp. 291] states that in the United States:

The regulations for Section 482 indicate that transactions between related parties must be priced as if they involved unrelated parties; that is arm's length pricing.

${ }^{5}$ Scholes and Wolfson (1992) [pp. 291] states that one of the methods for determining arm's length prices is by using a

comparable uncontrolled price (where a similar transaction between unrelated parties can be observed in the marketplace).

${ }^{6}$ Chown (1990) argues [pp. 49]:

Generally it can be assumed that there is no longer much scope for manipulating taxes by the use of artificial interest rates, although this still leaves plenty of opportunity for designing an optimum financial structure based on market rates.
} 
We show that it is optimal to choose a seniority structure such that the intra-firm parent debt has equal priority to the external debt. We show this by arguing that for any given probability of bankruptcy, the interest rate the parent is able to charge on its intra-firm loan is higher with equal seniority than with any other seniority structure. We show that the parent would sometimes choose to pay the external debt claims of the subsidiary in full, even when it is not contractually obligated to do so. This happens when the amount the parent saves by avoiding bankruptcy is larger than the additional amount the parent pays to meet external debt obligations of the subsidiary in full. ${ }^{7}$

The model generates several interesting empirical implications. In particular we show that higher corporate tax rates in the foreign country are associated with a larger proportion of debt financing by external debt, larger interest rates and a larger probability of bankruptcy, for the same level of total debt. Similarly, for any given level of financing, higher corporate tax rates in the home country are associated with a smaller proportion of subsidiary debt financing by external debt, smaller interest rates and a smaller probability of bankruptcy, for the same level of total debt.

\section{The Model}

We consider a one period model in which a wholly owned foreign subsidiary of a multinational corporation generates a single non-negative cash flow, denoted $y$, at the end of the period. The cash flow $y$ is assumed to be distributed with a density function denoted $f(y)$. We assume, for simplicity, that all agents are risk-neutral. Let $D$ denote the total required debt financing of the subsidiary of which $D^{p}$ is provided by the parent as intra-firm debt and $D^{f}=D-D^{p}$ is raised through external debt financing. All cash flows are measured in the same unit of currency. $\tau^{h}$ denotes the tax rate on corporate income in the parent country and $\tau^{f}$ denotes the tax rate in the country in which the foreign subsidiary's income is taxed. We assume, following the U.S. tax code, that the parent is allowed a foreign tax credit (FTC), limited to a maximum amount, for taxes paid in the foreign country. The FTC limitation, in the context of our model, is simply equal to $\tau^{h}$ times the taxable income

\footnotetext{
${ }^{7}$ This is consistent with the observation, made by Shapiro (1989) among others, that a parent would often meet the debt obligations of the subsidiary when the subsidiary defaults, even if it had no obligation to do so. Shapiro cites the results of two different surveys, Stobaugh (1970) and Business International Money Report (1986).
} 
of the subsidiary. ${ }^{8}$

We analyze the case when $\tau^{f}>\tau^{h}$. Since the FTC limitation is binding in this case, it becomes desirable for the multinational to transfer income from the subsidiary to the parent in the form of interest payments, since these are tax deductible in the foreign country. If instead, the income were declared in the form of dividends, the multinational would end up paying taxes on the foreign income at the foreign tax rate $\tau^{f}$ that is higher than the domestic tax rate $\tau^{h}$. Therefore, the firm would prefer intra-firm debt financing to equity financing for its subsidiary when $\tau^{f}>\tau^{h}$ and thus, $D$ can also be interpreted as the total required investment in the subsidiary. ${ }^{9}$

Since interest expense is tax deductible in the foreign country, the multinational parent firm has the incentive to charge as high an interest rate on its intra-firm loan to its subsidiary as possible. Tax authorities, well aware of such incentives, therefore, limit the interest rate that can be charged on intra-firm loans. The benchmark used in determining the allowed rate of interest on intra-firm loans is usually the market rate on comparable loans. To capture the intent of such tax regulations, we make the specific assumption that the interest rate that the parent is allowed to charge on its intra-firm loan cannot exceed the larger of either the risk-free rate, denoted $r$, or the interest rate the subsidiary pays on its external loan with equal or senior priority - the rate on the external loan being determined competitively in the external debt market. It is not necessary that we make this particular assumption about tax policy - what is important for our analysis is that the allowed interest rate on intra-firm debt be increasing in the interest rate on external debt.

We assume that there are costs associated with bankruptcy where bankruptcy is defined as an event in which the investors holding the external debt of the subsidiary are not paid the contractual amount in full. Bankruptcy costs are modeled by assuming that a fraction, denoted $b \in(0,1)$, of the available cash flow $y$ is dissipated in the bankruptcy proceedings and only $(1-b) y$ is available for distribution.

\footnotetext{
${ }^{8}$ See Scholes and Wolfson (1992).

${ }^{9}$ If $\tau^{f}<\tau^{h}$ then, in the context of our model, since intra-firm parent debt and equity result in an equivalent tax burden, the firm would not have any preference for one over the other. In a multi-period context, though, since U.S. taxation of dividends can be deferred until repatriated, the firm may have a preference for receiving dividends over interest payments. Consistent with this reasoning, Hines and Hubbard (1990) finds that in 1984, the average foreign tax rate paid by firms that paid dividends but no interest was $34 \%$ whereas the average tax rate paid by those that paid interest but no dividends was $51 \%$. Also, see Wolfson (1990).
} 


\subsection{The Priority Structure of Subsidiary Debt}

The optimal debt financing strategy for the subsidiary is determined by the tradeoff between tax savings due to deductibility of interest expense and bankruptcy costs. This tradeoff is affected by the priority structure of subsidiary debt since the choice of the priority structure affects the allowed interest rate on intra-firm debt and the bankruptcy costs associated with external debt. We show below that it is optimal to choose a seniority structure such that the intra-firm parent debt has equal priority to the external debt. We show this by arguing that keeping the probability of bankruptcy fixed, the interest rate the parent is able to charge on its intra-firm loan and the total tax savings are higher with equal seniority than with any other seniority structure.

First, consider the case in which the external debt of the subsidiary, $D_{J}^{f}$, is junior to that of the intra-firm parent debt, $D_{J}^{p}$. In this case, given the assumed structure of tax regulation, the firm will be allowed to charge only the risk-free rate, $r$, on the intra-firm parent debt. The face value of the parent debt, therefore, is equal to $(1+r) D_{J}^{p}$. Let $R_{J}$ denote one plus the interest rate on the external debt, $D_{J}^{f}$.

We show in the following proposition that given $D_{J}^{p}$ and $D_{J}^{f}$, it is always possible to construct an alternative policy with senior external debt whose payoffs are identical to those of the junior external debt in the original policy, the probability of bankruptcy remaining unaltered. Therefore, the bankruptcy costs under the two policies are identical but the alternative policy has the benefit that the firm is able to charge an interest rate that is higher than the risk-free rate on intra-firm parent debt that is now junior.

Proposition 1 For any policy in which the external debt is junior to the intra-firm parent debt, there exists a policy with senior external debt and junior intra-firm parent debt that dominates the given policy.

Proof: See the Appendix.

It is worth noting (from the discussion in the Appendix) that when the external debt is junior, the parent would sometimes choose to pay the subsidiary's external debt claims fully even when it is not contractually obligated to do so. This occurs when the cash flow dissipation in bankruptcy, by, exceeds the external debt claims $R_{J} D_{J}^{f}$. 
Our next step is to show that a policy in which the subsidiary's external debt is senior to the intra-firm debt is dominated by a policy in which some intra-firm debt has equal priority to the external debt. For simplicity, we assume that there is only one class of external debt.

Let $D_{S}^{f}$ denote the optimal level of external debt when the external debt is senior to the intra-firm debt and let $R_{S}$ denote one plus the interest rate on this external debt. In this case, the firm is bankrupt, if and only if the cash flow $y$ is less than the contractual payment $R_{S} D_{S}^{f}$ to the external debtholders.

We now show that there exists an alternative policy in which $D_{e}^{f}$ amount of external debt has equal priority with $D_{e}^{p}$ amount of intra-firm debt, the remaining intra-firm debt $\left(D-D_{e}^{f}-D_{e}^{p}\right)$ being junior, such that the probability of bankruptcy remains unaltered. Let $R_{e}$ denote one plus the interest rate on external debt $D_{e}^{f}$. Consider the situation in which the total available cash flow $y$ is less than the contractual debt obligations $R_{e}\left(D_{e}^{f}+D_{e}^{p}\right)$. If a proportional payment is made to both the external debt holders as well as the parent, the parent would receive $(1-b) y \frac{D_{e}^{p}}{D_{e}^{f}+D_{e}^{p}}$. If the parent decides to pay the subsidiary's external debtholders fully, they would not initiate the bankruptcy proceedings and the parent would receive $y-R_{e} D_{e}^{f}$. Clearly, if $y-R_{e} D_{e}^{f} \geq(1-b) y \frac{D_{e}^{p}}{D_{e}^{f}+D_{e}^{p}}$, the parent would choose to pay the external debtholders in full. The condition for bankruptcy, then, is equivalent to

$$
y<R_{e}\left(D_{e}^{f}+D_{e}^{p}\right) \frac{D_{e}^{f}}{D_{e}^{f}+b D_{e}^{p}} .
$$

Lemma 1 There exist $D_{e}^{p}$ and $D_{e}^{f}$ such that

$$
\begin{gathered}
R_{e}\left(D_{e}^{f}+D_{e}^{p}\right) \frac{D_{e}^{f}}{D_{e}^{f}+b D_{e}^{p}}=R_{S} D_{S}^{f}, \\
R_{e}>R_{S}, \\
D_{e}^{f}<D_{S}^{f} .
\end{gathered}
$$

Proof: See the Appendix.

The restriction (1) implies that the condition for bankruptcy under the alternative policy is identical to the one in which the external debt was senior and equal to $D_{S}^{f}$. Since the allowed intra-firm rate can be no more than the rate on external debt (of equal or senior priority), the result above $\left(R_{e}>R_{S}\right)$ implies that the firm can charge a higher interest rate on its intra-firm debt to the subsidiary when the external debt is of equal priority to some 
intra-firm debt than when it is senior. Since the total intra-firm debt under the new policy, $D-D_{e}^{f}$, is larger than the intra-firm debt under the old policy, $D_{S}^{p}$, the tax savings are larger. This is achieved without altering the condition for bankruptcy. Therefore, it follows that the policy of having $D_{e}^{f}$ external debt with equal priority to some intra-firm debt $D_{e}^{p}$, the rest of the intra-firm debt being junior, dominates the policy of having $D_{S}^{f}$ external debt that is senior to the intra-firm debt.

We have thus shown the following result

Proposition 2 For any policy in which the external debt is senior to the intra-firm debt, there exists a policy in which some intra-firm debt with equal priority to the external debt dominates the given policy.

Using similar arguments, the result above can be extended as follows.

Lemma 2 For any policy in which there is some intra-firm debt of equal priority to the external debt, there exists a policy in which a larger level of intra-firm parent debt that has equal priority to the external debt dominates the given policy.

Proof: See the Appendix.

Proposition 1 and Lemmas 1 and 2 lead to the following proposition.

Proposition 3 The parent firm would choose the entire intra-firm debt to be of equal priority to that of the external debt of the subsidiary.

\subsection{The Optimal Mix of Parent Debt and External Debt}

Having shown that the parent would choose the entire intra-firm debt to be of equal priority to that of the external debt, we now examine how the parent firm chooses the optimal level of external debt, $D^{f}$, as well as the intra-firm debt, $D^{p}=D-D^{f}$ for the subsidiary, where these debts are of equal priority. $R$ denotes one plus the interest rate on the external debt $D^{f}$.

For simplicity, we assume that the parent firm is risk-free and that it is able to raise funds for the intra-firm debt in the debt market at the risk-free rate. We also assume the 
parent's income is sufficiently high that it is able to take advantage of all tax deductions fully.

Recall that because of bankruptcy costs, the parent chooses to repay the external debtholders of the subsidiary in full, if and only if the cash flow

$$
y \geq R\left(D^{f}+D^{p}\right) \frac{D^{f}}{D^{f}+b D^{p}}=R D \theta
$$

where

$$
\theta \equiv \frac{D^{f}}{D^{f}+b D^{p}}
$$

The following table indicates the cash flow that accrues to various claimants to the subsidiary's cash flow as a function of $y$.

Table 1

\begin{tabular}{||l||c|c|c||}
\hline \hline & $0 \leq y<R D \theta$ & $R D \theta \leq y<R D$ & $R D \leq y$ \\
\hline \hline Gross Cash Flow & $y$ & $y$ & $y$ \\
\hline $\begin{array}{l}\text { Cash Flow Dissipated } \\
\text { in Bankruptcy }\end{array}$ & $b y$ & 0 & 0 \\
\hline $\begin{array}{l}\text { Cash Flow to External } \\
\text { Debtholders }\end{array}$ & $(1-b) y \frac{D^{f}}{D}$ & $R D^{f}$ & $R D^{f}$ \\
\hline $\begin{array}{l}\text { Debt Repayment to } \\
\text { the Parent }\end{array}$ & $(1-b) y \frac{D^{p}}{D}$ & $\left(y-R D^{f}\right)$ & $R D^{p}$ \\
\hline $\begin{array}{l}\text { Subsidiary's } \\
\text { Taxable Income }\end{array}$ & 0 & 0 & $\left(y-R D^{p}\right)$ \\
\hline $\begin{array}{l}\text { Debt Repayment to } \\
\text { Parent's Debtholders }\end{array}$ & $(1+r) D^{p}$ & $(1+r) D^{p}$ & $(1+r) D^{p}$ \\
\hline $\begin{array}{l}\text { Parent's } \\
\text { Taxable Income }\end{array}$ & $-(1-b) y \frac{D^{p}}{D}$ & {$\left[\left(y-R D^{f}\right)\right.$} & {$\left[R D^{p}\right.$} \\
\hline
\end{tabular}

First notice that when $R D \leq y$ (column 3), all debt claims of the subsidiary are paid in full. The subsidiary's taxable income is non-negative only in this case and equals $y-R D$. This income would be taxed at the rate $\tau^{f}$ in the foreign country. Since $\tau^{f}>\tau^{h}$, this income is not subject to any additional taxation in the parent's home country. When $R D \theta \leq y<R D$ (column 2), the parent chooses to pay the external debt claims of the subsidiary in full, even though it is not contractually obligated to do so. When $0 \leq y<R D \theta$ (column 1), the firm is in bankruptcy and all debt holders, since they have equal priority, receive proportional payment on their claims. Notice that a fraction, by, of the cash flow is 
dissipated in bankruptcy costs. The parent's taxable income equals the debt repayment by the subsidiary less the repayment to the parent's debtholders and is taxed at the rate $\tau^{h}$.

We now examine the debt pricing condition for the external debt.

$$
(1+r) D^{f}=\int_{0}^{R D \theta}(1-b) y \frac{D^{f}}{D} f(y) d y+R D^{f} \int_{R D \theta}^{\infty} f(y) d y .
$$

In general, there could be more than one value of $R$ that satisfies the above debt pricing condition. We assume that it is the smallest value of $R$ that satisfies the debt pricing condition that would prevail in equilibrium. Since the right hand side of the constraint (2) - which represents the expected payoff to the external debtholders - is zero when $R$ is zero, the partial derivative of the right hand side of the constraint with respect to $R$ must be positive if $R$ is indeed the smallest value that satisfies the constraint. Formally, this implies that

$$
\frac{\partial}{\partial R}\left[\int_{0}^{R D \theta}(1-b) y \frac{1}{D} f(y) d y+R \int_{R D \theta}^{\infty} f(y) d y\right]>0 .
$$

The debt pricing constraint (2), is equivalent to

$$
(1+r)=\int_{0}^{R D \theta}(1-b) y \frac{1}{D} f(y) d y+R \int_{R D \theta}^{\infty} f(y) d y
$$

Since $D^{f}+D^{p}=D$ we can express $D^{f}$ as the following function of $D^{p}$ :

$$
D^{f}\left(D^{p}\right) \equiv D-D^{p}
$$

Therefore $\theta$ could also be thought of as a function of $D^{p}$ :

$$
\theta\left(D^{p}\right) \equiv \frac{D-D^{p}}{D-(1-b) D^{p}}
$$

Let $R\left(D^{p}\right)$ denote the function that satisfies the constraint (4). Thus $R\left(D^{p}\right)$ satisfies the following identity.

$$
(1+r) \equiv \int_{0}^{R\left(D^{p}\right) D \theta\left(D^{p}\right)}(1-b) y \frac{1}{D} f(y) d y+R\left(D^{p}\right) \int_{R\left(D^{p}\right) D \theta\left(D^{p}\right)}^{\infty} f(y) d y \equiv G\left(R\left(D^{p}\right), \theta\left(D^{p}\right)\right) .
$$

Proposition 4 The larger the proportion of total debt financing of the subsidiary through intra-firm parent debt (which is equivalent to a smaller proportion through external debt financing), the smaller is the interest rate on the external debt. 
Proof: Differentiating the identity in (5) with respect to $D^{p}$, and rearranging, we get

$$
R^{\prime}\left(D^{p}\right)=\frac{-\frac{\partial G}{\partial \theta} \theta^{\prime}\left(D^{p}\right)}{\frac{\partial G}{\partial R}}
$$

Also, $-\frac{\partial G}{\partial \theta}=R^{2} D[1-(1-b) \theta]>0$. From (3), we know that the denominator of the above expression for $R^{\prime}\left(D^{p}\right)$ is positive. From the definition of $\theta\left(D^{p}\right)$, it follows that $\theta^{\prime}\left(D^{p}\right)=$ $\frac{-b D}{\left[D-(1-b) D^{p}\right]^{2}}<0$, which implies that $R^{\prime}\left(D^{p}\right)<0$

The intuition for this result is that when the proportion of external debt financing is larger, it is less likely that the external debtholders will be paid in full and more likely that the subsidiary will be declared bankrupt. Since a fraction of cash flow gets dissipated in bankruptcy proceedings, the external debtholders need to be compensated more in the nonbankrupt states which implies a larger interest rate. Notice that if there were no bankruptcy costs, i.e., $b$ were equal to zero, then $R^{\prime}\left(D^{p}\right)$ would also equal zero (since $\theta^{\prime}\left(D^{p}\right)=0$ for $b=0$ ). In other words, if there were no bankruptcy costs, the interest rate would obviously not depend on what proportion of financing is through external debt but would depend only on the total level of financing since both external as well as the intra-firm debt have equal seniority.

Proposition 5 The larger the proportion of total debt financing of the subsidiary through intra-firm parent debt (which is equivalent to a smaller proportion through external debt financing), the smaller is the probability of bankruptcy for the subsidiary.

Proof: The probability of bankruptcy for the subsidiary is

$$
\int_{0}^{R\left(D^{p}\right) D \theta\left(D^{p}\right)} f(y) d y
$$

We know from Proposition 4 that $R^{\prime}\left(D^{p}\right)<0$ and $\theta^{\prime}\left(D^{p}\right)<0$. Hence, the integral above is decreasing in $D^{p}$ since the upper limit of the integral, $R\left(D^{p}\right) D \theta\left(D^{p}\right)$, is decreasing in $D^{p}$.

The intuition for this result is that not only does a smaller proportion of debt financing through external debt imply a smaller interest rate but also that there is a larger incentive for the firm to avoid bankruptcy by paying the subsidiary's external debtholders in full: therefore the probability of bankruptcy is smaller.

Let us now examine how the optimal proportion of subsidiary debt financing that is raised through intra-firm parent debt is determined. The firm chooses the level of intra-firm 
debt financing $D^{p}$ so as to maximize the sum of the after-tax income of the subsidiary and the after tax income of the parent. Formally, the maximization problem can be expressed as:

$$
\begin{aligned}
& \operatorname{Max}_{D^{p}} W\left(D^{p}\right) \equiv\left(1-\tau^{f}\right) \int_{R\left(D^{p}\right) D}^{\infty}\left[y-R\left(D^{p}\right) D\right] f(y) d y \\
&+\left(1-\tau^{h}\right)\left[\int_{0}^{R\left(D^{p}\right) D \theta\left(D^{p}\right)}(1-b) y \frac{D^{p}}{D} f(y) d y\right. \\
&+\int_{R\left(D^{p}\right) D \theta\left(D^{p}\right)}^{R\left(D^{p}\right) D}\left[y-R\left(D^{p}\right) D^{f}\left(D^{p}\right)\right] f(y) d y \\
&\left.+\int_{R\left(D^{p}\right) D}^{\infty} R\left(D^{p}\right) D^{p} f(y) d y\right] \\
&-\left(1-\tau^{h}\right)\left[(1+r) D^{p}\right] .
\end{aligned}
$$

The first term in the expression above represents the expected after tax income of the subsidiary. The remaining terms represent the expected after tax income of the parent from its intra-firm loan to the subsidiary. The taxable incomes of the subsidiary and the parent in different states are given in Table 1.

Differentiating $W\left(D^{p}\right)$ with respect to $D^{p}$, and substituting for $(1+r)$ from $(5)$, we get

$$
\begin{aligned}
W^{\prime}\left(D^{p}\right)= & \left\{( 1 - \tau ^ { h } ) \left[D^{p} \int_{R D}^{\infty} f(y) d y\right.\right. \\
& \left.\left.-\left(D-D^{p}\right) \int_{R D \theta}^{R D} f(y) d y\right]-\left(1-\tau^{f}\right) D \int_{R D}^{\infty} f(y) d y\right\} R^{\prime}\left(D^{p}\right)
\end{aligned}
$$

The optimal choice of the relative proportions of external versus intra-firm financing reflects the following tradeoff. As the firm increases the proportion of intra-firm debt, the interest rate decreases. This, on one hand reduces the tax savings the firm enjoys on its intra-firm debt but on the other hand, also reduces the bankruptcy costs associated with the external debt.

Proposition 6 The subsidiary's debt financing would not be entirely through external debt financing.

Proof: Substituting $D^{p}=0$ and the fact that $\theta(0)=1$ in $(6)$, and since $R^{\prime}(0)<0$ from Proposition 4, we get

$$
W^{\prime}(0)=\left\{-\left(1-\tau^{f}\right) D \int_{R(0) D}^{\infty} f(y) d y\right\} R^{\prime}(0)>0 .
$$


The intuition for this result is as follows. When there is no intra-firm debt, increasing its proportion reduces the bankruptcy costs associated with the external debt. This also reduces the interest rate allowed on intra-firm debt, but there is no corresponding loss in tax savings on account of the decrease in interest rate because the level of intra-firm debt is zero to begin with.

Proposition 7 The subsidiary's debt financing would not be entirely through intra-firm parent debt financing.

Proof: Substituting $D^{p}=D$ in $(6)$, and since $R^{\prime}(D)<0$ from Proposition 4 , we get

$$
W^{\prime}(D)=\left\{\left(\tau^{f}-\tau^{h}\right) D \int_{R(D) D}^{\infty} f(y) d y\right\} R^{\prime}(D)<0
$$

The intuition for this result is as follows. When all debt financing is through intra-firm debt, reducing the intra-firm debt slightly increases the interest rate. This increases the tax savings on the intra-firm debt. Since almost all the debt financing is through intra-firm debt, the tax savings resulting from the increase in the allowed interest rate on intra-firm debt more than offsets the increase in bankruptcy costs on account of the small increase in external debt.

\subsection{Tax Regimes and Subsidiary Debt Financing}

We now examine some comparative statics results. Let $D^{p *}$ denote the value of $D^{p}$ that solves the maximization problem. Since, we know from Propositions 6 and 7 that the optimum is an interior solution, $D^{p *}$ must satisfy the first order condition. It is useful to define $V\left(D^{p *}\right) \equiv W^{\prime}\left(D^{p *}\right) / R^{\prime}\left(D^{p *}\right)$. We can write the first order condition as $V\left(D^{p *}(a), a\right) \equiv 0$, where $a$ denotes the parameter of interest for the comparative statics exercise. Differentiating with respect to $a$ and rearranging, we get

$$
\frac{d D^{p *}}{d a}=-\frac{\frac{\partial}{\partial a} V\left(D^{p *}(a), a\right)}{V^{\prime}\left(D^{p *}(a), a\right)}
$$

where ' denotes derivative with respect to the first argument. Since $R^{\prime}\left(D^{p}\right)<0$, the second order condition $W^{\prime \prime}\left(D^{p *}(a), a\right)<0$ implies that $V^{\prime}\left(D^{p *}(a), a\right)>0$. Therefore,

$$
\operatorname{Sign}\left[\frac{d D^{p *}}{d a}\right]=-\operatorname{Sign}\left[\frac{\partial}{\partial a} V\left(D^{p *}(a), a\right)\right] .
$$


Proposition 8 The higher is the foreign tax rate $\tau^{f}$, the smaller is the proportion of subsidiary financing through intra-firm parent debt.

Proof:

$$
\frac{\partial}{\partial \tau^{f}} V\left(D^{p *}\left(\tau^{f}\right), \tau^{f}\right)=D \int_{R D}^{\infty} f(y) d y>0 .
$$

Therefore from (7) it follows that

$$
\frac{d D^{p *}}{d \tau^{f}}<0
$$

The intuition behind this result is that a higher $\tau^{f}$ implies larger tax savings on the interest expense on intra-firm debt. Hence, the firm would be willing, at the margin to increase the proportion of external financing, despite an increase in bankruptcy costs, since this increases the allowed rate on the intra-firm debt.

Proposition 9 The higher is the domestic tax rate $\tau^{h}$, the larger is the proportion of subsidiary financing through intra-firm parent debt.

Proof:

$$
\frac{\partial}{\partial \tau^{h}} V\left(D^{p *}\left(\tau^{h}\right), \tau^{h}\right)=-\left[D^{p *} \int_{R D}^{\infty} f(y) d y-\left(D-D^{p *}\right) \int_{R D \theta}^{R D} f(y) d y\right] .
$$

¿From (6) and the first order condition $W^{\prime}\left(D^{p *}\right)=0$, the term in the square brackets is positive which implies that

$$
\frac{\partial}{\partial \tau^{h}} V\left(D^{p *}\left(\tau^{h}\right), \tau^{h}\right)<0
$$

Therefore from (7) it follows that

$$
\frac{d D^{p *}}{d \tau^{h}}>0
$$

The intuition is that a higher $\tau^{h}$ implies smaller tax savings associated with a given interest rate. Hence, at the margin, the firm would be willing to decrease the proportion of external debt financing since the benefits from a decrease in bankruptcy costs would more than offset the decrease in tax savings on account of a lower allowed rate on intra-firm debt.

\subsection{Does It Pay to Make Bankruptcy More Costly?}

The comparative statics results for $D^{p *}$ with respect to the bankruptcy cost parameter $b$ are ambiguous. To see this, we first differentiate the debt pricing constraint (4) with respect to 
$b$. Rearranging, we get

$$
f(R D \theta) \frac{\partial}{\partial b}(R D \theta)=-\frac{1}{1-(1-b) \theta} \frac{1}{R D} \int_{0}^{R D \theta} y f(y) d y<0 .
$$

Now, differentiating $V\left(D^{p *}(b), b\right)$ with respect to $b$, we get

$$
\frac{\partial}{\partial b} V\left(D^{p *}(b), b\right)=\left(\tau^{f}-\tau^{h}\right) D^{2} f(R D) \frac{\partial R}{\partial b}+\left(1-\tau^{h}\right)(D-D p) f(R D \theta) \frac{\partial}{\partial b}(R D \theta) .
$$

Notice that from (8), the second term is negative. The sign of the first term depends on the sign of $\frac{d R}{d b}$. Differentiating the debt pricing constraint with respect to $b$ and rearranging, we get

$$
\frac{\partial R}{\partial b}=\frac{R D^{p}}{D-(1-b) D^{p}}-\frac{\frac{1}{D} \int_{0}^{R D \theta} y f(y) d y}{[1-(1-b) \theta] R D \theta f(R D \theta)} .
$$

Notice that the sign of $\frac{\partial R}{\partial b}$ itself is ambiguous. The intuition is that if bankruptcy becomes more costly as the fraction $b$ lost in the bankruptcy proceedings increases, on one hand this tends to increase the interest rate since the external debtholders have to be compensated more in the non-bankrupt states. On the other hand, the parent is more likely to pay the external debtholders fully in order to avoid bankruptcy altogether. The net effect, in general, is ambiguous. Even if we were to assume that interest rate $R$ increases as $b$ increases, the effect on the optimal proportion of intra-firm debt is ambiguous. While a higher $b$ implies higher bankruptcy costs, a higher interest rate also implies higher tax savings on the intra-firm debt. The net effect, in general, is ambiguous.

Since a high value of the bankruptcy cost parameter $b$ may imply a higher interest rate, one might wonder if it also implies a higher value of after-tax income for the multinational. This could lead to an interesting strategy for the firm to deliberately put in place systems that increase the fraction of cash-flow that gets dissipated in bankruptcy proceedings. The following Proposition demonstrates that such a strategy would not be optimal.

Proposition 10 The after-tax income $W\left(D^{p *}(b), b\right)$ of the firm is decreasing in the bankruptcy cost parameter $b$.

Proof: We know from the Envelope theorem that

$$
\frac{d}{d b} W\left(D^{p *}(b), b\right)=\frac{\partial}{\partial b} W\left(D^{p *}(b), b\right) .
$$


Partially differentiating $W\left(D^{p *}(b), b\right)$ with respect to $b$ and rearranging, we get

$$
\begin{aligned}
\frac{\partial}{\partial b} W\left(D^{p *}(b), b\right)= & \left\{( 1 - \tau ^ { h } ) \left[D^{p *} \int_{R D}^{\infty} f(y) d y\right.\right. \\
& \left.\left.-\left(D-D^{p *}\right) \int_{R D \theta}^{R D} f(y) d y\right]-\left(1-\tau^{f}\right) D \int_{R D}^{\infty} f(y) d y\right\} \frac{\partial R}{\partial b} \\
& -\left(1-\tau^{h}\right) \frac{D^{p *}}{D} \int_{0}^{R D \theta} y f(y) d y .
\end{aligned}
$$

Notice that from (6) and the first order condition, the first term is equal to zero. Since the second term is negative, we get

$$
\frac{d}{d b} W\left(D^{p *}(b), b\right)<0
$$

The intuition behind this result is that it never pays for the firm to increase the interest rate by increasing the fraction $b$ dissipated in bankruptcy since the firm can always increase the interest rate by increasing the proportion of external debt. Since, at the optimum, the firm is already at a level of interest rate, where the marginal cost of increasing the interest rate just equals the marginal benefit from tax savings, increasing the interest rate by increasing $b$ does not help but only hurts since a larger fraction of cash flow is dissipated in bankruptcy.

\section{Empirical Implications}

We now collect in one place the empirical implications of the arguments formalized in the earlier sections. Our purpose here is to focus attention away from the formalism and to emphasize the intuition behind these results.

Implication 1 The parent will sometimes choose to pay the external debt obligations of its subsidiary in full, even when it is not contractually obligated to do so, in order to prevent external debtholders from initiating bankruptcy proceedings. The parent is more likely to do this when the value of the subsidiary's assets is high than when it is low.

The intuition is that when the value of the subsidiary's assets is high, the relative amount dissipated in bankruptcy proceedings is high. Therefore, the incentive to avoid bankruptcy is higher. When the value of subsidiary's assets is sufficiently high, the potential savings by avoiding bankruptcy exceeds the additional payment made to the external debtholders. 
Implication 2 The parent firm will choose the entire intra-firm debt to be of equal priority to that of the external debt.

The intuition for this result is that for any given probability of bankruptcy, the interest rate the parent is able to charge on its intra-firm loan is higher with equal seniority than with any other seniority structure, which results in larger tax savings.

Implication 3 A higher proportion of subsidiary debt financing through external debt is associated with a higher interest rate and a higher probability of bankruptcy, for the same level of total debt.

The intuition is that when the proportion of external debt financing is larger, it is less likely that the firm will pay off its external debtors in full and more likely that the firm will be declared bankrupt. Since a fraction of subsidiary firm value gets dissipated in bankruptcy proceedings, the external debtholders need to be compensated more in the non-bankrupt states which implies a larger interest rate. The probability of bankruptcy is higher both because the interest rate is higher and because the parent is less likely to avoid bankruptcy by paying the subsidiary's external debtholders in full.

Implication 4 The subsidiary's debt financing is not entirely through external debt or entirely through intra-firm parent debt.

From Implication 3, increasing the proportion of subsidiary external debt financing increases the interest rate required by investors. A higher interest rate implies higher tax savings on the intra-firm debt, however it also implies higher bankruptcy costs. Therefore, if there is no external debt financing it makes sense for the firm to increase it slightly since the increased tax savings on the large amount of intra-firm debt more than offsets the corresponding increase in bankruptcy costs on the small amount of external debt. Similarly, if there is no intra-firm debt financing, it makes sense to increase it. A reduction in the proportion of the external debt leads to a reduction in bankruptcy costs as well as the interest rate allowed on intra-firm debt. The reduction in bankruptcy costs is not offset by the reduction in tax savings on account of the decrease in interest rate since there was no intra-firm debt to begin with. 


\section{Implication 5 1. The higher the foreign corporate tax rate:}

- The larger is the proportion of subsidiary financing through external debt.

- The larger is the interest rate, for the same level of total debt.

- The larger is the probability of bankruptcy, for the same level of total debt.

2. The higher the domestic corporate tax rate:

- The smaller is the proportion of subsidiary financing through external debt.

- The smaller is the interest rate, for the same level of total debt.

- The smaller is the probability of bankruptcy, for the same level of total debt.

A higher foreign corporate tax rate implies larger tax savings on the interest expense on intra-firm debt. Therefore, at the margin the firm would be willing to increase the proportion of external debt financing, despite the increase in bankruptcy costs since this increases the allowed interest rate on intra-firm debt. From Implication 3, this would also lead to a higher probability of bankruptcy. The intuition for the other case is similar.

\section{Concluding Remarks}

We have argued that multinational subsidiaries located in countries with corporate tax rates higher than in the parent's home country would want to use both external as well as intrafirm debt. To minimize its tax burden, the multinational would charge as high an interest rate on intra-firm debt as allowed by the tax authorities. The interest rate on external debt, since it is set freely by the market, can be used to justify to tax authorities the interest rate the parent sets on intra-firm debt. The optimal mix of external debt and parent debt is determined by the trade off between tax savings and bankruptcy costs associated with external debt.

The model generates several testable implications about the effect of corporate tax rates in the parent's home country and the foreign country in which the subsidiary is located on the subsidiary's debt financing mix. One prediction is that lower corporate tax rates in the parent's home country or higher tax rates at the subsidiary's location are associated with a larger proportion of external debt financing. Hence, a substantial change in the tax code, 
e.g., such as the 1986 tax changes in the U.S. that lowered the corporate tax rates to $34 \%$, is predicted to result in U.S. corporations relying more heavily on external subsidiary debt in countries with higher corporate tax rates. Similarly, foreign multinationals would tend to rely less on external financing for their U.S. subsidiaries and more heavily on intra-firm debt.

An issue of some interest in the literature is whether the capital structure choice by multinational subsidiaries differs from that of comparable local firms. ${ }^{10}$ Since intra-firm debt does not entail any bankruptcy costs, we would expect multinational subsidiaries to assume a larger total (parent and external) debt in their capital structures than similar local firms - for the case where the tax rates the subsidiary faces are greater than the corporate tax rates in the parent's home country. It is reasonable to expect, however, that the external debt component of the subsidiary's debt will be less than the total debt of a similar local firm. This is because the local firm, since it does not have access to intra-firm financing, would be more willing to accept higher bankruptcy costs at the margin than would the multinational subsidiary that does have access to intra-firm debt.

We have argued in the paper that the interest rate on subsidiary external debt may be critical in determining the interest rate permitted on intra-firm debt. It is plausible, therefore, that external debt contracts would be structured in a manner such that, to the extent possible, the return to investors is in the form of interest payments rather than other means. For example, the subsidiary may prefer to pay a higher interest rate on a bank loan rather than incur certain fixed charges associated with initiating the loan. Also, one cannot rule out the possibility of firms misrepresenting the true cost of external debt financing.

The analysis provided in the paper abstracts away from several interesting issues. First, the analysis is done using a one period model. This misses the complexity of tax planning and strategy in a multi-period dynamic framework. Second, the analysis is done assuming that the parent firm is essentially riskless and generates sufficiently large income to capture all potential tax shields. Relaxing this assumption would allow an analysis of more complex and richer transfer pricing issues. We leave these issues for future research.

\footnotetext{
${ }^{10}$ See Eiteman, Stonehill and Moffett (1991); Shapiro (1989); and references therein.
} 


\section{Appendix}

\section{Proof of Proposition 1}

Clearly, when the cash flow $y \geq(1+r) D_{J}^{p}+R_{J} D_{J}^{f}$, the external debtholders are paid the contractual amount in full. However when $y<(1+r) D_{J}^{p}+R_{J} D_{J}^{f}$, there are two cases to consider.

- Case 1: First case arises when the bankruptcy cost parameter $b$ is low enough such that the maximum cash flow dissipated in bankruptcy $b\left[(1+r) D_{J}^{p}+R_{J} D_{J}^{f}\right]$ is less than the face value of the external debt $R_{J} D_{J}^{f}$. Clearly, in this case, the parent lets the subsidiary go bankrupt. The subsidiary is bankrupt, in this case, if and only if $y<(1+r) D_{J}^{p}+R_{J} D_{J}^{f}$. The external debtholders, in case of bankruptcy, receive $\operatorname{Max}\left\{0,(1-b) y-(1+r) D_{J}^{p}\right\}$.

If we were to replace the intra-firm parent debt with a senior external debt with face value $(1+r) D_{J}^{p}$, the condition for bankruptcy would remain unaltered and the original external debtholders would receive identical payoffs. At the same time, the interest expense the firm would be able to charge would go up since earlier, the parent was only allowed to charge the risk-free rate on the senior intra-firm debt.

- Case 2: Second case arises when the bankruptcy cost parameter is high, i.e., when $R_{J} D_{J}^{f}<b\left[(1+r) D_{J}^{p}+R_{J} D_{J}^{f}\right]$. Now, when $y<\frac{R_{J} D_{J}^{f}}{b}$, the cash flow dissipated in bankruptcy, by is less than the contractual value of the external debt, $R_{J} D_{J}^{f}$. But if $y>\frac{R_{J} D_{J}^{f}}{b}$, the cash flow dissipated in bankruptcy, by is greater than $R_{J} D_{J}^{f}$, so the parent would choose to pay the subsidiary's external debtholders in full, even though the external debt was junior to the intra-firm parent debt.

Rearranging the condition

$$
b\left[(1+r) D_{J}^{p}+R_{J} D_{J}^{f}\right]>R_{J} D_{J}^{f}
$$

we get

$$
(1-b) \frac{R_{J} D_{J}^{f}}{b}<(1+r) D_{J}^{p}
$$

When $y<\frac{R_{J} D_{J}^{f}}{b}$, from the above condition, $(1-b) y<(1+r) D_{J}^{p}$. Since in this case, the parent lets the subsidiary go bankrupt, the external debtholders receive nothing. 
When $y>\frac{R_{J} D_{J}^{f}}{b}$, the parent pays the external debtholders in full and they receive $R_{J} D_{J}^{f}$.

Suppose the firm were to replace the senior intra-firm debt $D_{J}^{p}$ and the junior external debt $D_{J}^{f}$ with a senior external debt with face value equal to $\frac{R_{J} D_{J}^{f}}{b}$ and some junior intra-firm debt. The condition for bankruptcy remains unaltered since the firm is bankrupt if and only if $y<\frac{R_{J} D_{J}^{f}}{b}$. The external debt, with a total face value of $\frac{R_{J} D_{J}^{f}}{b}$, could be thought of as consisting of two parts, a senior part that has a face value equal to $\left(\frac{R_{J} D_{J}^{f}}{b}-R_{J} D_{J}^{f}\right)$ and a junior part that has a face value equal to $R_{J} D_{J}^{f}$. The maximum cash flow available for distribution, in case of bankruptcy, is equal to $(1-b) \frac{R_{J} D_{J}^{f}}{b}$. This is equal to the face value of the senior part of the external debt. Therefore, the cash flow to the junior part, in case of bankruptcy, is equal to zero. Of course, if there is no bankruptcy, the cash flow to the junior part of the external debt is equal to the face value $R_{J} D_{J}^{f}$. Thus, this junior part of the external debt is identical to the junior external debt when the firm has senior parent debt of amount $D_{J}^{p}$. But, in this case, the firm is able to charge a higher interest expense since now it would be allowed to charge a rate that is greater than the risk-free rate on its junior intra-firm debt.

\section{Proof of Lemma 1}

To see that there exist values of $D_{e}^{p}$ and $D_{e}^{f}$ such that restriction (1) is satisfied, observe that $0 \leq D_{e}^{f} \leq D$. For $D_{e}^{f}=0$, the LHS is equal to zero and less than the RHS. For $D_{e}^{f}=D$, all debt is external and the LHS is simply equal to the face value of this external debt which must be greater than the RHS. Since the LHS is continuous in $D_{e}^{f}$, we know that there exist values of $D_{e}^{f}$ and $D_{e}^{p}$ such that restriction (1) is satisfied.

A competitive market for external debt implies that the following debt pricing restriction would be satisfied.

$$
(1+r) D_{S}^{f}=\int_{0}^{R_{S} D_{S}^{f}}(1-b) y f(y) d y+R_{S} D_{S}^{f} \int_{R D^{f}}^{\infty} f(y) d y
$$

The restriction (1) can be rewritten as follows.

$$
\frac{R_{e} D_{e}^{f}}{R_{S} D_{S}^{f}}=\frac{D_{e}^{f}+b D_{e}^{p}}{D_{e}^{f}+D_{e}^{p}} \equiv \alpha .
$$


The external debt under the alternative policy is priced follows.

$$
(1+r) D_{e}^{f}=\frac{D_{e}^{f}}{D_{e}^{f}+D_{e}^{p}} \int_{0}^{R_{S} D_{S}^{f}}(1-b) y f(y) d y+R_{e} D_{e}^{f} \int_{R_{S} D_{S}^{f}}^{\infty} f(y) d y .
$$

Since,

$$
\frac{D_{e}^{f}}{D_{e}^{f}+D_{e}^{p}}<\frac{D_{e}^{f}+b D_{e}^{p}}{D_{e}^{f}+D_{e}^{p}} \equiv \alpha
$$

and from (10),

$$
R_{e} D_{e}^{f}=\alpha R_{S} D_{S}^{f}
$$

substituting (12) and (13) in (11), we get

$$
(1+r) D_{e}^{f}<\alpha \int_{0}^{R_{S} D_{S}^{f}}(1-b) y f(y) d y+\alpha R_{S} D_{S}^{f} \int_{R_{S} D_{S}^{f}}^{\infty} f(y) d y=\alpha(1+r) D_{S}^{f} .
$$

The above condition implies that $D_{e}^{f}<\alpha D_{S}^{f}$ which substituting in (13) implies that $R_{e}>$ $R_{S}$ and that $D_{e}^{f}<D_{S}^{f}$.

\section{Proof of Lemma 2}

Let $D_{e}^{f}$ denote the optimal level of external debt when $D_{e}^{p}$ is the level of intra-firm debt with equal priority. The condition for bankruptcy and the debt pricing condition are as follows.

$$
\begin{gathered}
y<R_{e}\left(D_{e}^{f}+D_{e}^{p}\right) \frac{D_{e}^{f}}{D_{e}^{f}+b D_{e}^{p}} \equiv Z \\
(1+r) D_{e}^{f}=\frac{D_{e}^{f}}{D_{e}^{f}+D_{e}^{p}} \int_{0}^{Z}(1-b) y f(y) d y+R_{e} D_{e}^{f} \int_{Z}^{\infty} f(y) d y .
\end{gathered}
$$

Now suppose the firm increases the level of intra-firm debt that has the same priority as the external debt to $D_{E}^{p}>D_{e}^{p}$ and chooses the level of external debt $D_{E}^{f}$ such that the condition for bankruptcy remains unaltered to $y<Z$. It follows that

$$
\frac{R_{E} D_{E}^{f}}{R_{e} D_{e}^{f}}=\frac{D_{e}^{f}+D_{e}^{p}}{D_{e}^{f}+b D_{e}^{p}} \frac{D_{E}^{f}+b D_{E}^{p}}{D_{E}^{f}+D_{E}^{p}} \equiv \alpha .
$$

The debt pricing condition now is

$$
(1+r) D_{E}^{f}=\frac{D_{E}^{f}}{D_{E}^{f}+D_{E}^{p}} \int_{0}^{Z}(1-b) y f(y) d y+R_{E} D_{E}^{f} \int_{Z}^{\infty} f(y) d y .
$$

Substituting $R_{E} D_{E}^{f}=\alpha R_{e} D_{e}^{f}$ in (16) and from (14), we get

$$
(1+r) D_{E}^{f}=\alpha(1+r) D_{e}^{f}+\left(\frac{D_{E}^{f}}{D_{E}^{f}+D_{E}^{p}}-\alpha \frac{D_{e}^{f}}{D_{e}^{f}+D_{e}^{p}}\right) \int_{0}^{Z}(1-b) y f(y) d y
$$


For $D_{E}^{f}<D_{e}^{f}$, substituting from (15) and rearranging, we get

$$
\left(\frac{D_{E}^{f}}{D_{E}^{f}+D_{E}^{p}}-\alpha \frac{D_{e}^{f}}{D_{e}^{f}+D_{e}^{p}}\right)<0
$$

which implies that $D_{E}^{f}<\alpha D_{e}^{f}$ which substituting in $R_{E} D_{E}^{f}=\alpha R_{e} D_{e}^{f}$ implies that $R_{E}>$ $R_{e}$. This implies that the firm can charge a higher interest rate on its intra-firm debt by increasing the intra-firm debt and appropriately decreasing the external debt such that the condition for bankruptcy is unaltered. 


\section{References}

1. Business International Money Report, 1986, "Determining Overseas Debt/Equity Ratios", January 27, p.26.

2. Chown, John F., 1990, Tax Efficient Foreign Exchange Management, Quorum Books.

3. Eiteman, David K., Arthur I. Stonehill and Michael H. Moffett, 1991, Multinational Business Finance, Sixth Edition, Addison Wesley Publishing Company.

4. Errunza, Vihang R., 1979, "Financing MNC Subsidiaries in Central America", Journal of International Business Studies, Fall, 88-93.

5. Hines, James R., Jr. and R. Glenn Hubbard, 1990, "Coming Home to America: Dividend Repatriations by U.S. Multinationals", in Assaf Razin and Joel Slemrod, editors, Taxation in a Global Economy, University of Chicago Press and National Bureau of Economic Research, 161-200.

6. Robbins, Sidney M. and Robert B. Stobaugh, 1972, "Financing Foreign Affiliates", Financial Management, Vol. 1, No. 3, 56-65.

7. Scholes, Myron S. and Mark A. Wolfson, 1992, Taxes and Business Strategy, Prentice Hall, New Jersey.

8. Shapiro, Alan C., 1978, "Financial Structure and Cost of Capital in the Multinational Corporation", Journal of Financial and Quantitative Analysis, June, 211-226.

9. Shapiro, Alan C., 1989, Multinational Financial Management, Third Edition, Allyn and Bacon.

10. Stobaugh, Robert B., 1970, "Financing Foreign Subsidiaries of U.S.-Controlled Multinational Enterprises", Journal of International Business Studies, Summer, 43-64.

11. Stonehill, Arthur and Thomas Stitzel, 1969, "Financial Structure and Multinational Corporations", California Management Review, Vol. XII, No. 1, 91-96.

12. Wolfson, Mark, 1990, Comment on "Coming Home to America: Dividend Repatriations by U.S. Multinationals", in Assaf Razin and Joel Slemrod, editors, Taxation in a Global Economy, University of Chicago Press and National Bureau of Economic Research, 200-207. 